IJMS 27(1), 21-47 (2020)

How to cite this article:

Koay, Y. Y., Keh, C. G., Tang, S. E., Tan, Y. T., \& Chan, L.M. (2020). Can the "tax the rich, subsidise the poor" policy improve financial satisfaction among Malaysians? International Journal of Management Studies, 26(2), 21-47. https://doi.org/10.32890/ijms.27.1.2020.8005

\title{
CAN THE “TAX THE RICH, SUBSIDISE THE POOR" POLICY IMPROVE FINANCIAL SATISFACTION AMONG MALAYSIANS?
}

\author{
YING-YIN KOAY \\ CHIA-GUAN KEH \\ SIU-ENG TANG \\ YAN-TENG TAN \\ *LING-MENG CHAN \\ Faculty of Business and Finance \\ Universiti Tunku Abdul Rahman, Malaysia \\ *Corresponding author: chanlm@utar.edu.my
}

\begin{abstract}
"Tax the rich, subsidise the poor" is deemed one of the typical finance characteristics of democracy and a solution in reducing income inequality. The Malaysian government has also adopted this strategy in its income redistribution policy. Evidently, this strategy can minimise the income gaps at the country level. However, it is doubtful if it can be effectively done at the individual level. The rich have to pay more while the poor can enjoy the 'free' income. Would that lead to financial satisfaction? Hence, the main objective of this study was to investigate the impact of individual perceptions on the government's democratic act in implementing "tax the rich, subsidise the poor" policy for financial satisfaction among Malaysians. For an empirical analysis, this paper discusses the study conducted which used the sixth wave of the World Value Survey (WVS) data with 1290 respondents and is regressed by the ordered logit and ordered probit modelling. The results indicated that the democratic act of 'taxing the rich and subsidising the poor' in reality reduces financial satisfaction among Malaysians. In contrast, these same Malaysians wish for a larger income difference as an incentive for individual efforts. In view of this, the government and policy makers should
\end{abstract}


make revisions to the current progressive taxation system or look for other alternative taxation systems which may be seen as fairer and can improve financial satisfaction among Malaysians at each income level.

Keywords: Financial satisfaction, Malaysia, tax and subsidy.

Received: 13/2/2020 Revised: 01/06/2020 Accepted: 07/06/2020 Published: 23/07/2020

\section{Introduction}

"Tax the rich, subsidise the poor" is deemed a typical characteristic of financial policy in a democracy (McGee, Benk \& Yüzbaşı, 2019; McGee \& Yoon, 2018; McGee, Yoon \& Liu, 2019). Democratic governments can help reduce the income inequality among its citizens by imposing a higher tax rate on the high income group (rich) and redistributing the income by providing subsidies for the lower income group (poor). For example, some of the democratic countries such as Belgium, Sweden and Denmark have adopted progressive tax systems, where higherincome households will have to pay more taxes than the lower-income households (Oishi, Schimmack \& Diener, 2012). This has caused the low and middle-income groups to live more contentedly and thus financially satisfied. In fact, this progressive taxation system has also been adopted in Malaysia.

Recently, the Malaysian government announced an increase in the tax rates imposed on high income individuals from 28 percent to 30 percent in Budget 2020 (BNM, 2019). At the same time on the other end, the government also subsidised the low-income group through some financial aid such as, Bantuan Rakyat 1 Malaysia (BR1M) since 2012, which has since been renamed "Bantuan Sara Hidup" (Subsistence Aid) in 2019 (Saravanamuttu \& Mohamad, 2020). According to Oxfam (2019), the government can collect more tax revenue under a progressive taxation system, provide more services for its citizens and welfare to the poor to make them financially satisfied. At the national level, this 'tax the rich, subsidise the poor' policy can improve income distribution measures. But, can it impact the individual level in terms of financial satisfaction (FS)?

Some studies revealed that these progressive tax systems did not always make the average earners financially satisfied (Oishi et al., 2012). It could be that the benefits of the redistribution is not channelled proportionately to both the average and the rich earners 
(Ravallion \& Lokshin, 2000). Intuitively, the rich people have to pay higher taxes, while the poor can 'enjoy' the 'free' income through government subsidies. This raises a research question - How does the democratic act of the Malaysian government in implementing 'tax the rich, subsidise the poor' policy affect the financial satisfaction of its citizens?

Numerous empirical researches revealed that financial satisfaction is one of the vital predictors and a big contributor to subjective well-being (Diener \& Chan, 2011; Ngamaba, Armitage, Panagioti \& Hodkinson, 2020; Ng \& Diener, 2014; Ng, Russell \& Kang, 2019). Financial satisfaction can be expressed as positive perceptions of an individual on his/her current financial situation (Ali, Rahman \& Bakar, 2015). It is related more to the subjective well-being of individuals in developing countries since money would fulfil essential needs such as food, healthcare and education (Ng \& Diener, 2014). Additionally, this financial satisfaction is progressively utilised as a legitimate and significant indicator to gauge and judge the effects of the government policy (Hicks, Tinkler \& Allin, 2013; Joo \& Grable, 2004; Ta, Zhu \& Fu, 2020). However, relatively few empirical researches have focused on how to improve financial satisfaction, especially in the case of Malaysia.

To close the research gap on financial satisfaction literature, this study also intends to further investigate, besides "taxing the rich, subsidising the poor" policy, how other factors such as income level, financial situation, income inequality, food security, employment sector, marital status, age and gender can influence financial satisfaction among Malaysians. For an empirical analysis, this study employed the most recent wave of World Value Survey (WVS) data with a sample of 1290 respondents throughout all the Malaysian states and the Federal Territory of Kuala Lumpur. Then, the data was regressed by a few modelling approaches, namely the ordered logit and ordered probit specifications. Lastly, the rest of the paper is organised as follows. A review of literature is discussed in the next section, followed by the methodology used and the results. A conclusion is included in the last section of the paper.

\section{Literature Review}

\section{Financial Satisfaction (FS)}

Campbell (1981) defined financial satisfaction as a sub-construct of general well-being that depicts a situation of being healthy, happy 
and free of any financial liabilities. It is the financial fulfilment of the individual in his/her current financial pursuits, as it is one of the essential components of the good life. This definition was further enhanced by Zimmerman (1995) who defined that the financial satisfaction is the satisfaction that individuals have attained with the current financial situations. Individuals have the tendency to evaluate their well-beings or their satisfaction levels based on certain benchmarks or comparisons with others. Through financial satisfaction, the individuals are not only able to fulfil their basic financial needs and have sufficient fundings in hand for current and future use, but they also have the abilities to handle any emergencies or limitations on finance related matters (Hira \& Mugenda, 1998). When individuals achieve this state of financial well-beings, their financial stressors, such as financial strains, credit card debts, financial risks and others, are reduced.

According to the study by Joo and Grable (2004), financial satisfaction can be achieved via two dimensions - subjective well-being and objective well-being. Financial satisfaction asserts that a sense of financial well-being depends not only on the measurement of objective and subjective financial conditions, but also on how a person perceives the objective attributes of the financial situation after comparing these attributes against certain comparison standards. Subjective well-being, also known as non-material financial satisfaction, mainly derived from the satisfaction over the emotions and psychological needs; such as past and future financial outcomes, perceptions of income adequacy and economic condition satisfaction (debt, saving or income), while objective well-being is the materialistic financial satisfaction derived from the accumulation of income and wealth.

The measurement for financial satisfaction seems to be the widest measure of the variables, whilst stimulating the evaluations on the overall financial situations. Researchers in the past employed both single and multiple measures to measure financial satisfaction. The most commonly used global financial satisfaction were anchored by a single question, such as, "How satisfied are you with your financial situation?" by Morgan (1992), and, "How comfortable and well-off are you financially?" by Greenley, Greenberg and Brown (1997). This similar instrument continues to be employed by recent studies, such as the World Values Survey Association (2009) and Joo and Grable (2004). Joo and Grable (2004) employed a self-anchoring 10-point stairstep questions on their respondents to measure financial satisfaction. This suggested that the selection of a measurement tool for financial 
satisfaction depends on the type of approach which tends to mirror each other in terms of predicting the possible results.

Past studies suggested that there are a variety of factors that directly and indirectly influence the individual's financial satisfaction, including demographic factors (age, marital status, gender etc.), financial attitudes, financial incomes, financial behaviours, incentives and basic psychological needs. For instance, while education and income have shown an indirect relationship with financial satisfaction in the Joo and Grable (2004) study, some financial behaviour like saving practices and credit management have more significant and direct impacts on the financial satisfaction compared with the demographic factors. In the study by Robb and Woodyard (2011), positive financial behaviour was found to have contributed significantly towards the financial satisfaction of their consumers who had been using credit counselling.

\section{Taxing the Rich and Subsidising the Poor and Financial Satisfaction}

The government has been constantly putting in effort to reduce the income disparity between the rich and the poor; the most common practice being transferring the income from the rich to the poor through the tax system. Taxing the rich and subsidising the poor may have an effect on personal financial satisfaction. This is the main concern of the study. However, there have been very few past studies on the relationship between the progressive tax system and personal financial satisfaction. In view of the relationship between financial satisfaction and life satisfaction, happiness and subjective well-being, we had already reviewed the links between progressive tax and life satisfaction, happiness, and/or subjective well-being in past studies.

Most of the previous studies show that the relationship between taxing the rich, subsidising the poor and subjective well-being is positive (Griffith, 2003; Oishi et al., 2012; Cheung, 2018). There are two reasons that contribute to these results. Firstly, income has declining marginal returns (Griffith, 2003; Cheung, 2018). Poor individuals are thought to be happier than the rich with the same amount of money. The portion of social well-being that has increased through taxing the rich is higher among the poor than the portion of social well-being losses among the rich. Overall, the society gains more welfare through taxing the rich.

Secondly, subjective well-being is diminished when one's income is less when compared to others (Blanchflower \& Oswald, 2004; Cheung 
\& Lucas, 2016; Luttmer, 2005). Subjective well-being improves with lesser comparisons. The government can help to reduce the comparisons by closing the income gap through the imposition of higher taxes on the rich, and hence improving the subjective wellbeing of the society. Based on the two reasons mentioned, it is hypothesised that:

$\mathrm{H}_{1}$ : There is a significant positive relationship between taxing the rich and subsidising the poor and financial satisfaction.

\section{Income Level and Financial Satisfaction}

Money is very important to sustain everyone's life. But can money make everyone happy? Given his thoughts in the 1970's, Richard Easterlin suggested that at the individual level, a higher income is associated with higher satisfaction, but only up to a certain extent. When a person is reasonably rich, more money does not have much effect on his satisfaction. Over the decades, many studies have discussed how income level is associated with personal wellness (Diener, 1984; George, 1992; Larson, 1978). However, there are very few studies on how income level is linked with financial satisfaction. From the previous studies, two types of income have been discussed and used, namely, personal income (Hsieh, 2003; Hsieh, 2004; DePianto, 2011) and household income (Brown \& Gray, 2016; Hsieh, 2003; Hsieh, 2004; Joo \& Grable 2004; Vera-Toscano, Ateca-Amestoy, \& Serrano-Del-Rosal, 2006).

Most of the studies reported that there is a positive association between both personal and household income with financial satisfaction (Hsieh, 2003; Hsieh, 2004; Joo \& Grable, 2004 Vera-Toscano et al., 2006). DePianto (2011) found personal income to have the strongest positive effect on white male financial satisfaction, while Hansen, Slagsvold and Moum (2008) suggested that this personal income will affect older adults more than younger adults. Vera-Toscano et al. (2006) added that there is a positive and significant relationship between household income and personal financial satisfaction. Hsieh (2004) found the same results after controlling the demographic variables. In addition, by studying different age groups, Hsieh (2003) found similar results across all age groups. Based on the early and recent studies, we can hypothesise that:

$\mathrm{H}_{2}$ : There is a significant positive relationship between income level and financial satisfaction. 
IJMS 27(1), 21-47 (2020)

\section{Household Financial Situation and Financial Satisfaction}

In this study, the household financial situation is defined as, how respondents behave financially in their daily lives, which includes managing cash, credit and savings. Based on a review on past studies, an individual's financial satisfaction can be either objective or subjective; thus, it is important that a positive household financial situation improve the financial well-being. Joo (2008) suggested that a positive household financial situation helps to maximise family happiness and also achieve a sense of life satisfaction, which in turn, indirectly helps to build up to life contentment. Moreover, a good household financial situation related to the major areas of finance including personal finance basics, borrowing money, savings and investments would help to improve the financial well-being of the individuals (Huston, 2010). This is consistent with the study by Robb and Woodyard (2011), where if the individual practises good financial behaviour, such as paying credit card bills on time, sufficient fund allocations for contingencies and emergencies, do price comparisons before shopping, it will improve their financial well-beings.

Generally, a positive relationship has been found between the household financial situation and financial satisfaction (Huston, 2010; Joo, 2008). It can be seen that proper financial recording helps to improve the financial well-being of individuals. Robb and Woodyard (2011) acknowledged that individuals who always kept written financial records were more satisfied with their financial well-beings, as the more frequent they saved on a regular basis for specific goals, their perceptions of economic well-beings are bound to improve. The financial satisfaction among those who are more solvent tends to be better. Thus, the following hypothesis is proposed:

$\mathrm{H}_{3}$ : There is a significant positive relationship between household financial situations with financial satisfaction.

\section{Income Inequality and Financial Satisfaction}

When the income gap between the poor and rich is too wide, the major section of the society is unhappy. The income levels of others rather than his own are more likely to affect an individual's satisfaction (Ball \& Chernova, 2008; Senik, 2005). An individual's happiness decreases when the incomes of the others increase (Luttmer, 2005). Most of the researches use Gini coefficient at national or state level as an indicator for income discrepancy. Many findings showed that 
these national or state level datasets and satisfaction are negatively related (Alesina, Di Tella \& MacCulloch, 2004; Delhey \& Dragolov, 2014; Hagerty, 2000). Studies revealed that European respondents are less happy when the gap of the incomes widens (Alesina et al., 2004; Delhey \& Dragolov, 2014). Others suggested that the low income group (Cooper, McCausland, \& Theodossiou, 2013) and the middle income group (Hasting, 2019) are the most dissatisfied when income discrepancy increases. According to Yan and Wen (2020), income discrepancies deteriorate the urban resident's satisfaction. Roth, Hahn and Spinath (2017) found that the negative effect between income inequality and overall satisfaction is mediated by economic worries. While little research has been done on income inequality with financial satisfaction on the individual level, this research which was based on the subjective questionnaires probably shed more light on the relationship between the two variables. Based on most of the findings of the above studies, the following hypothesis is proposed.

$\mathrm{H}_{4}$ : There is a significant negative relationship between income inequality and financial satisfaction.

\section{Food Security and Financial Satisfaction}

According to the Utility Theory (Bruni, 2007), the individual's behaviour is based on the principle that people regularly rankorder their decisions according to their own likes/dislikes. Thus, it can be explained that individuals, given their particular financial satisfaction will do their best to maximise this utility, which is to ensure a sufficient food supply for their households. If the individuals facing financial constraints want to fulfil their perceived needs in food adequacy, they may accumulate debt if their current financial abilities do not match their food adequacy expectations. In addition, the accumulated debt may cause emotional stress and lower their financial satisfaction significantly. Additionally, the World Values Survey Association (WVSA), the association that conducts world value surveys (WVS), included the surveys on basic values such as food, safe accommodation, medication, and cash, in different countries and continents as it is believed that all these basic needs are parts of overall financial well-being (WVSA, 2009).

Due to financial constraints, people may have difficulties to get food supplies, and as a result may not be satisfied with their financial circumstances. In other words, food is a necessity for living, if people have no financial problems to meet their food adequacies, in turn, 
they will find it more financially satisfying because they have no financial constraints to meet their basic needs in life. Thus, this study posits the following hypothesis:

$\mathrm{H}_{5}$ : There is a significant positive relationship between food security and financial satisfaction.

\section{Working with Public Sector and Financial Satisfaction}

Research has found that the income earned in the public sector is higher than in the private sector (Heckman \& Hotz,1986; Pisani \& Pagán 2003; Pradhan \& Van Soest, 1995) especially in the less developed nations (Thomas, 1990). Thus, personal financial satisfaction declines if an individual is working in the private sector. Besides income, other studies revealed that those working in the public sector are more job-secure and less worried about their future retirement life, and thus are more satisfied (Sahi, 2013; Luechinger, Meier, \& Stutzer, 2010; Ferrer-i-Carbonell \& Gërxhani, 2011). Other factors like rewards, work quality, promotions, guidance, and teamwork have an effect on job satisfaction and can directly affect life satisfaction (Mafini, 2014). Viewing the situation in Malaysia, wages in the public sector is generally higher than in the private sector; and with stricter dismissal procedures, the public sector is an overall better working environment. Based on this, we can hypothesise that:

$\mathrm{H}_{6}$ : There is a significant positive relationship between working with the public sector and financial satisfaction.

\section{Demographic Factors and Financial Satisfaction}

Demographic variables such as marital status, age and gender have been associated with aspects of financial satisfaction. For instance, most of the past studies have strongly suggested that there is a positive relationship between age and financial satisfaction. In the study by Plagnol (2011), it was suggested that older adults have a higher level of financial satisfaction when compared with younger adults, who have less assets and liabilities to manage. This indicated that as the respondents age, their financial satisfaction will also improve mainly because they are more likely to be in better financial conditions with less liabilities and more assets compared to the younger adults.

Besides that, gender is also one of the common controlled variables which have a significant relationship with financial satisfaction. As 
there are more and more women joining the labour workforce, they help to contribute to the family income and indirectly increase female involvement in the household's financial decisions. With their participation, financial satisfaction among the women improves compared with the men (Bonke \& Browing, 2009).

A review of past studies has indicated that financial satisfaction can enhance marital satisfaction, and in a broader sense, it can create a happy life for the married couple. This is consistent with most research studies on financial satisfaction, where if the married couple encountered frequent financial crises or arguments, it will contribute to their dissatisfaction in the marriage relationship, which could result in divorce. In the study by Stack and Eshleman (1998), it was acknowledged that marriage not only provides relationship satisfaction between both parties, but it also provides economic protection and enhances the household income. It can be clearly seen that married couples tend to enjoy a better living standard compared with their own single lives before marriage. Their marriage thus has helped the couple to have better and systematic planning in managing their financial activities. Thus, the following hypothesis is proposed for the demographic variables:

$\mathrm{H}_{7}$ : There is a significant relationship between demographic factors (Age, Gender, and Marital Status) and financial satisfaction.

\section{Methodology}

This study employs a sample of 1290 respondents (after filtering out 10 respondents who had incomplete data) from the latest wave 6 of World Value Survey (WVS) data. The WVS (www. worldvaluessurvey.org) is a worldwide collaboration of social scientists studying human beliefs, values, and motivations all of which can affect social and political lives. The WVS has conducted this survey in almost 100 countries, covering about 90 percent of the world's populations with the same standard questionnaire. As such, the WVS data has been widely used in studies such as economics, social sciences, political science and religions. Hence, the contributions of WVS is highly recognised in journal publications as well as some world reports such as the World Happiness Report 2012 released by the Sustainable Development Solutions Network (Helliwell, Layard \& Sachs, 2012). 
After reviewing the past studies, the following empirical model is proposed:

$\begin{aligned} \text { FS }= & \alpha^{\prime}+\beta_{1} \text { Tax }_{i}+\beta_{2} \text { Income }_{i}+\beta_{3} \text { Finance }_{i}+\beta_{4} \text { Incentive }_{i}+\beta_{5} \text { Food }_{i}+\beta_{6} \text { Public }_{i}+ \\ & \beta_{7} \text { Married }_{i}+\beta_{8} \text { Age }_{i}+\beta_{9} \text { Male }_{i}+\varepsilon_{i}\end{aligned}$

where FS represents the level of respondent's perceived financial satisfaction. This data is obtained via the item, "How satisfied are you with the financial situation of your household?" with the original 10 -scaled responses. This item is commonly used to indicate the respondent's financial satisfaction level (Białowolski, 2018; Frijters, 2000; Migheli, 2019). In order to fulfil the parallel assumptions underlying the ordered logit/probit models, this item has been rescaled to a five-stepped scale; $\alpha^{\prime}$ are the cut-off values; $\beta$ represents the estimates of regressors; and $\varepsilon$ is the disturbance term and i denotes the i-the respondent. The study measures the impact of individuals' perceptions on the Malaysian government's democratic act of implementing "taxing the rich, subsidising the poor" on financial satisfaction among Malaysians based on a single item from the WVS. The respondents were asked to rank from 1 to 10 their agreement to the statement: "The government's 'tax the rich and subsidise the poor' policy is an essential characteristic of democracy" (WVS, 2011, p. 12). This item has commonly been used in the recent research on "Should governments tax the rich and subsidise the poor?" (McGee, Benk \& Yüzbaşı, 2019; McGee \& Yoon, 2018; McGee et al., 2019).

Additionally, this study also includes other control variables into Equation (1) to explain Malaysian financial satisfaction more comprehensively. They are income level (Income), financial situations (Finance), perceptions on income inequality (Incentive), the basic needs for food (Food), the employment sector (Public), marital status (Married), age (Age), and gender (Male). Finance is obtained through the question "During the past year, did your family (read out and code one answer): 1 . Set aside for savings and borrowings; 2. Spend some savings; 3 . Just managed to get by; 4 . Save money.". For Incentive, the respondents are asked to locate their preferences for inequality in a range from 1 to 10 (where 1 implies agreement with the statement "Income should be more equal", and 10 implies agreement with the statement "We need a larger income difference as incentives for individual effort").The inclusion of those control variables are made based on the previous findings as per discussed in the literature review part of this study. The details of all the variables are displayed in Table 1. 
Financial satisfaction ( $F S)$, a dependent variable is measured using an item with a 5 -step scale. In other words, this dependent variable is in an ordinal scaled measurement. Hence, the suitable modelling approaches for the ordinal scaled variable are the ordered logit and ordered probit modelling approaches. The obtained coefficients from the ordered logit modelling indicated the ln odd ratio of being financially satisfied (scale=1, 2, 3, 4, and 5) with a respective one unit change in the independent variable. On the other hand, the obtained coefficients from the ordered probit modelling showed the utility index of being financially satisfied (scale $=1,2,3,4$, and 5) with a respective one unit change in the independent variable. Thus, Equation (1) is estimated by two approaches, the cross-sectional ordered logit and ordered probit models.

\section{Table 1}

Variables Scale and Questions

\begin{tabular}{|c|c|c|}
\hline Variable & Scale & Questions \\
\hline $\begin{array}{l}\text { Financial } \\
\text { Satisfaction }(F S)\end{array}$ & $\begin{array}{l}\text { From } 1-\text { not at all satisfied to } 5 \text { - very } \\
\text { satisfied }\end{array}$ & $\begin{array}{l}\text { How satisfied are } \\
\text { you with the financial } \\
\text { situation of your } \\
\text { household? }\end{array}$ \\
\hline $\begin{array}{l}\text { Individual } \\
\text { perceptions on } \\
\text { the Malaysian } \\
\text { government's } \\
\text { democratic } \\
\text { act on } \\
\text { implementing } \\
\text { "tax the rich, } \\
\text { subsidize the } \\
\text { poor" (Tax) }\end{array}$ & $\begin{array}{l}1 \text { - strongly disagree to } 10 \text { - strongly } \\
\text { agree }\end{array}$ & $\begin{array}{l}\text { Respondents are } \\
\text { asked to rank from } 1 \\
\text { to } 10 \text { their agreement } \\
\text { to the statement: } \\
\text { "Governments tax the } \\
\text { rich and subsidize the } \\
\text { poor is an essential } \\
\text { characteristic of } \\
\text { democracy." }\end{array}$ \\
\hline $\begin{array}{l}\text { Income level } \\
\text { (Income) }\end{array}$ & $\begin{array}{l}\text { From } 1 \text { - lowest income decile to } 10 \text { - } \\
\text { highest income decile }\end{array}$ & $\begin{array}{l}\text { On this card is an } \\
\text { income scale on which } \\
1 \text { indicates the lowest } \\
\text { income group and } 10 \\
\text { the highest income } \\
\text { group in your country. }\end{array}$ \\
\hline
\end{tabular}

(continued) 
IJMS 27(1), 21-47 (2020)

\begin{tabular}{|c|c|c|}
\hline Variable & Scale & Questions \\
\hline $\begin{array}{l}\text { Household } \\
\text { financial } \\
\text { situation } \\
\text { (Finance) }\end{array}$ & $\begin{array}{l}1 \text { - Set aside for savings and } \\
\quad \text { borrowings } \\
2 \text { - Spend some savings } \\
3 \text { - Just managed to get by } \\
4 \text { - Save money }\end{array}$ & $\begin{array}{l}\text { During the past year, } \\
\text { did your family } \\
\text { (read out and code } \\
\text { one answer): } 1 \text {. Set } \\
\text { aside for savings and } \\
\text { borrowings; } 2 \text {. Spend } \\
\text { some savings; } 3 \text {. Just } \\
\text { managed to get by; } 4 \text {. } \\
\text { Save money }\end{array}$ \\
\hline $\begin{array}{l}\text { Income } \\
\text { Inequality } \\
\text { (Incentives) }\end{array}$ & 1 - Yes, 0 - Otherwise & $\begin{array}{l}\text { People are asked to } \\
\text { locate their preferences } \\
\text { for inequality in a range } \\
\text { from } 1 \text { to } 10 \text { (where } \\
1 \text { implies agreement } \\
\text { with the statement } \\
\text { "Income should be } \\
\text { more equal", and } 10 \\
\text { implies agreement } \\
\text { with the statement "We } \\
\text { need a larger income } \\
\text { difference as incentives } \\
\text { for individual effort." }\end{array}$ \\
\hline $\begin{array}{l}\text { Basic need for } \\
\text { food (Food) }\end{array}$ & From 1 - always to 4 - never & $\begin{array}{l}\text { In the last } 12 \text { months, } \\
\text { how often have you } \\
\text { or your family gone } \\
\text { without enough food } \\
\text { to eat? }\end{array}$ \\
\hline $\begin{array}{l}\text { Employment } \\
\text { Sector (Public) }\end{array}$ & 1 - Public, 0 - Private & $\begin{array}{l}\text { Are you working in } \\
\text { the public sector or the } \\
\text { private sector? }\end{array}$ \\
\hline $\begin{array}{l}\text { Marital Status } \\
\text { (Married) }\end{array}$ & 1 - Married , 0 - Otherwise & $\begin{array}{l}\text { Are you married or } \\
\text { single? }\end{array}$ \\
\hline $\begin{array}{l}\text { Age } \\
(A g e)\end{array}$ & Years & How old are you? \\
\hline $\begin{array}{l}\text { Gender } \\
\text { (Male) }\end{array}$ & 1 - Male, 0 - Female & Male or Female? \\
\hline
\end{tabular}

\section{Cross-Sectional Ordered Logit Model}

The underlying probability function in the ordered logit model follows a cumulative logistic distribution denoted by $\Phi($.$) and density$ function denoted by $\varphi($.$) . For this study, five levels of perceived$ 
financial satisfaction $(j=1,2,3,4$, and 5$)$ were set. Hence, there were four cuts (denoted by $\tau_{\mathrm{j}}$ ) in the proposed ordered logit model. For a five-level response, FS* is the latent variable, they were:

$$
\begin{aligned}
& \text { Level 1: } \tau_{0} \leq \mathrm{FS}^{*}<\tau_{1} \\
& \text { Level 2: } \tau_{1} \leq \mathrm{FS}^{*}<\tau_{2} \\
& \text { Level 3: } \tau_{2} \leq \mathrm{FS}^{*}<\tau_{3} \\
& \text { Level 4: } \tau_{3} \leq \mathrm{FS}^{*}<\tau_{4} \\
& \text { Level 5: } \tau_{4} \leq \mathrm{FS}^{*}<\tau_{5}
\end{aligned}
$$

In a concise form, the logistic form of the model is defined as the log of the ratio of probability of levels under or equal to a given cut to the probability of those over the cut, for each ascending level of cuts:

$$
\ln [\operatorname{Prob}(F S \leq f s \mid x) / \operatorname{Prob}(F S>f s \mid x)]
$$

where

$$
\operatorname{Prob}(x)=\frac{1}{1-\exp \left(-\left(\tau_{j}-x \beta\right)\right.}
$$

where fs indicates the level of FS (scale =1, 2, 3, 4, and 5) while $x$ denotes all the regressors in Equation (1).

\section{Cross-Sectional Ordered Probit Models}

In the order probit model, the $\varepsilon$ in Equation (1) is presumed to be normally distributed (with a mean of zero and variance equals to one) with cumulative distribution denoted by $\Phi($.$) and density function$ denoted by $\varphi($.). Given a level of perceived financial satisfaction, an individual falls in category $n$ if $\mu_{\mathrm{n}-1}<\mathrm{fs}^{*}<\mu_{\mathrm{n}}$. The perceived financial satisfaction data, $\mathrm{fs}$, are related to the underlying latent variable $\mathrm{fs}^{*}$, through thresholds $\mu_{n^{\prime}}$ where $n=1 \ldots . .5$. Thus, we have the following probabilities for each level of perceived happiness:

$$
\operatorname{Prob}(f s=n)=\Phi\left(\mu_{n}-\beta^{\prime} x\right)-\Phi\left(\mu_{n-1}-\beta^{\prime} x\right), n=1 \ldots 5
$$

where $\mu_{0}=0$ and $\mu_{5}=+\infty$ and $\mu_{1}<\mu_{2}<\mu_{3}<\mu_{4}$ are defined as three thresholds between which categorical responses of perceived happiness are estimated. The thresholds $\mu$ show the range of the normal distribution associated with the specific values of the response variable. The remaining parameters, $\beta$, represent the effect of changes in regressors on the underlying scale. For data sensitivity and robustness results checks, this study also re-scaled the financial satisfaction variable into a binary 
response variable $(1=$ being satisfied with the financial circumstances, 0 otherwise). Then, Equation (1) will be re-estimated using the logit and probit modelling approaches.

\section{Findings and Discussion}

Table 2 displays the descriptive statistics of both dependent and independent variables. In order to avoid the multicollinearity problem in the analysis, the correlation analysis was performed (Table 3). All the coefficients of correlation were found to be less than 0.80 . This shows that there was no cause for worry about multicollinearity that always shows up in the cross-sectional data analysis in the empirical analysis. Table 4 indicates the regression results of Equation (1). Column 1 in Table 4 are the results of ordered logit modelling while Column 2 shows the outcomes of ordered probit modelling on perceived financial satisfaction with five scales. To show the robustness of the results, the financial satisfaction was re-scaled into binary responses where 1 denoted that respondents were satisfied with their financial situation, 0 means otherwise. As such, the Columns 3 and 4 are the logit and probit modelling results on the binary responses for perceived financial satisfaction. Nevertheless, the empirical analysis mainly focused on Columns 1 and 2.

Table 2

Descriptive Statistic Summary

\begin{tabular}{lccccc}
\hline Variable & Observation & Mean & $\begin{array}{c}\text { Standard } \\
\text { Deviation }\end{array}$ & Minimum & Maximum \\
\hline FS & 1290 & 3.48 & 0.98 & 1 & 5 \\
Tax & 1290 & 6.68 & 2.84 & 1 & 10 \\
Income & 1290 & 6.00 & 1.83 & 1 & 10 \\
Finance & 1290 & 3.32 & 0.73 & 1 & 4 \\
Incentive & 1290 & 6.65 & 2.63 & 1 & 10 \\
Food & 1290 & 3.86 & 0.46 & 1 & 4 \\
Public & 1290 & 0.13 & 0.34 & 0 & 1 \\
Married & 1290 & 0.68 & 0.46 & 0 & 1 \\
Age & 1290 & 39.99 & 13.91 & 18 & 80 \\
Male & 1290 & 0.51 & 0.50 & 0 & 1 \\
\hline
\end{tabular}


IJMS 27(1), 21-47 (2020)

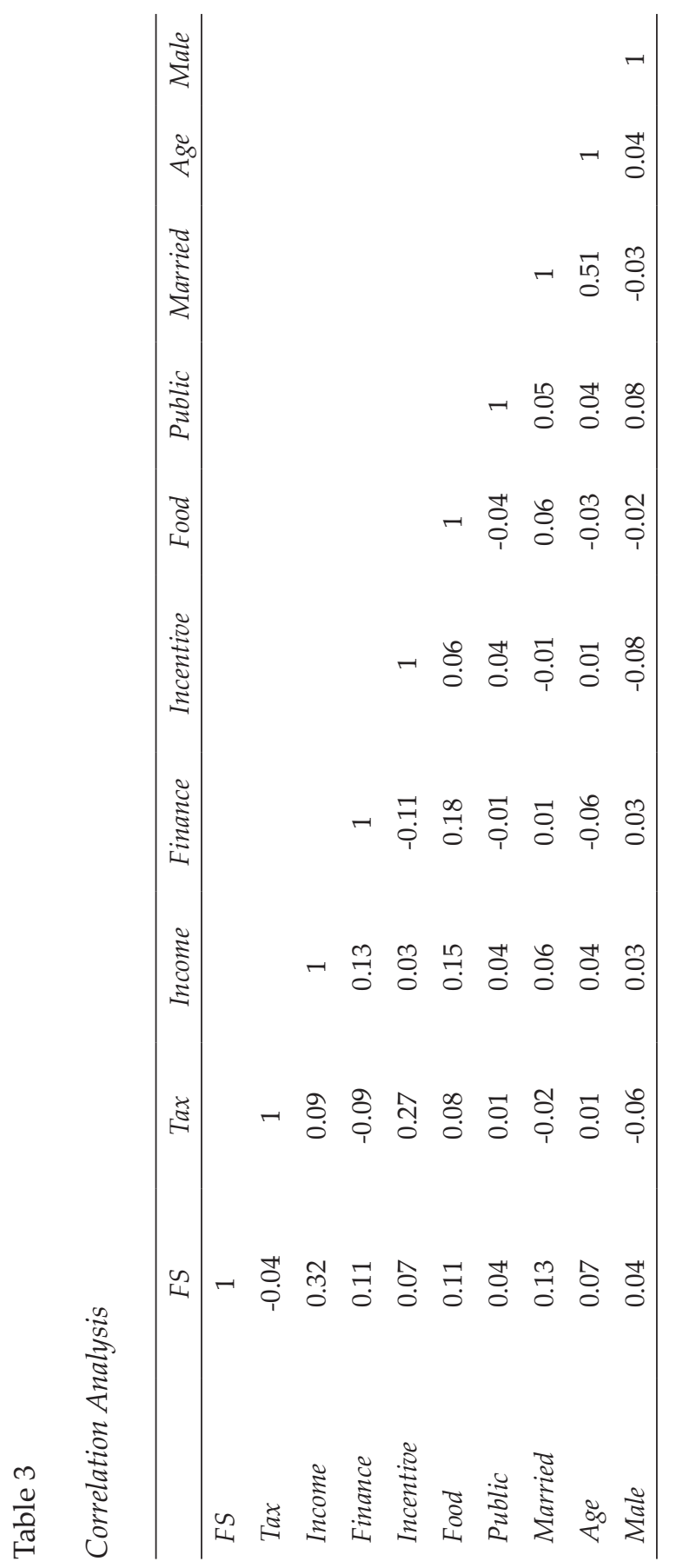


IJMS 27(1), 21-47 (2020)

Table 4

Regression Analysis for Malaysian Financial Satisfaction (FS)

\begin{tabular}{|c|c|c|c|c|}
\hline Variables & $\begin{array}{l}\text { Ologit } \\
(1)\end{array}$ & $\begin{array}{c}\text { Oprobit } \\
(2)\end{array}$ & $\begin{array}{l}\text { Logit } \\
(3)\end{array}$ & $\begin{array}{r}\text { Probit } \\
(4)\end{array}$ \\
\hline \multirow[t]{2}{*}{ Tax } & $-0.06^{* * *}$ & $-0.03^{* * *}$ & $-0.05^{* *}$ & $-0.03^{* *}$ \\
\hline & $(0.02)$ & $(0.01)$ & $(0.02)$ & $(0.01)$ \\
\hline \multirow[t]{2}{*}{ Income } & $0.37^{* * *}$ & $0.19^{* * *}$ & $0.38^{* * *}$ & $0.23^{* * *}$ \\
\hline & $(0.03)$ & $(0.02)$ & $(0.04)$ & $(0.02)$ \\
\hline \multirow[t]{2}{*}{ Finance } & $0.19^{* * *}$ & $0.11^{* * *}$ & $0.18^{* *}$ & $0.11^{* *}$ \\
\hline & $(0.07)$ & $(0.04)$ & $(0.08)$ & $(0.05)$ \\
\hline \multirow[t]{2}{*}{ Incentive } & $0.06^{* * *}$ & $0.04^{* * *}$ & $0.08^{* * *}$ & $0.05^{* * *}$ \\
\hline & $(0.02)$ & $(0.01)$ & $(0.02)$ & $(0.01)$ \\
\hline \multirow[t]{2}{*}{ Food } & $0.25^{* *}$ & $0.14^{* *}$ & $0.39^{* * *}$ & $0.24^{* * *}$ \\
\hline & $(0.11)$ & $(0.07)$ & $(0.14)$ & $(0.09)$ \\
\hline \multirow[t]{2}{*}{ Public } & 0.22 & 0.10 & 0.21 & 0.13 \\
\hline & $(0.15)$ & $(0.09)$ & $(0.18)$ & $(0.11)$ \\
\hline \multirow[t]{2}{*}{ Married } & $0.33^{* *}$ & $0.22^{* * *}$ & 0.24 & 0.14 \\
\hline & $(0.13)$ & $(0.07)$ & $(0.15)$ & $(0.09)$ \\
\hline \multirow[t]{2}{*}{ Age } & 0.01 & 0.00 & 0.01 & 0.00 \\
\hline & $(0.00)$ & $(0.00)$ & $(0.01)$ & $(0.00)$ \\
\hline \multirow[t]{2}{*}{ Male } & 0.11 & 0.07 & 0.11 & 0.07 \\
\hline & $(0.10)$ & $(0.06)$ & $(0.12)$ & $(0.07)$ \\
\hline \multirow{2}{*}{$\begin{array}{l}\text { Constant } \\
\text { cut1 }\end{array}$} & $0.99^{*}$ & 0.49 & & \\
\hline & $(0.52)$ & $(0.30)$ & & \\
\hline \multirow{2}{*}{$\begin{array}{l}\text { Constant } \\
\text { cut2 }\end{array}$} & $2.24^{* * *}$ & $1.11^{* * *}$ & & \\
\hline & $(0.51)$ & $(0.30)$ & & \\
\hline \multirow{2}{*}{$\begin{array}{l}\text { Constant } \\
\text { cut3 }\end{array}$} & $4.33^{* * *}$ & $2.31^{* * *}$ & & \\
\hline & $(0.52)$ & $(0.31)$ & & \\
\hline \multirow{2}{*}{$\begin{array}{l}\text { Constant } \\
\text { cut } 4\end{array}$} & $6.41^{* * *}$ & $3.52^{* * *}$ & & \\
\hline & $(0.54)$ & $(0.31)$ & & \\
\hline \multirow[t]{2}{*}{ Constant } & & & $-5.08^{* * *}$ & $-3.10^{* * *}$ \\
\hline & & & $(0.66)$ & $(0.39)$ \\
\hline Observations & 1,290 & 1,290 & 1,290 & 1,290 \\
\hline
\end{tabular}


Most of the studies from the European countries showed that higher taxes imposed on the high-income group and subsidising the poor did help to improve the subjective well-being (Cheung, 2018; Griffith, 2003; Oishi et al., 2012). However, the results from this study provide contrasting results, demonstrating that if the government implements the progressive tax which taxes the rich and subsidises the poor, it ruins the concept of financial satisfaction among Malaysians (ologit coefficient $=-0.06$, oprobit coefficient $=-0.03$, $p$-value $=0.00$ ). This could probably be because taxing the rich and subsidising the poor could be seen as an unfair system where hard work is not given due recognition and appreciation (Blanchflower \& Oswald, 2004; Cheung \& Lucas, 2016; Luttmer, 2005). Furthermore, the benefit of redistribution of the progressive tax may not be equally or proportionately channelled to the average or rich earners (Ravallion \& Lokshin, 2000). Therefore, these results may not sufficiently convince the Malaysian government to implement the policy that taxes the rich and subsidises the poor.

As predicted, the income level is positively related to the likelihood of being more satisfied with the respondent's financial situation (ologit coefficient $=0.37$, oprobit coefficient $=0.19, \mathrm{p}$-value $=0.00$ ). These findings are consistent with the previous studies done by Brown and Gray (2016) and DePianto (2011). In general, a higher income can make a person wealthier and raise financial satisfaction higher. Furthermore, a higher income allows people to afford a better quality of life through for instance, owning a house, buying imported cars or enjoying luxury holidays. Indirectly, their social status will also improve and they will be more financially satisfied. Since income is an important contributor to financial satisfaction, the government could revise the minimum wage from time to time to make the lower income group become more satisfied with their financial circumstances.

Furthermore, it was also found that the household financial situation greatly matters in the determination of financial satisfaction (ologit coefficient $=0.19$, oprobit coefficient $=0.11$, p-value $=0.01$ ). The household that has savings tends to be more satisfied with the finances compared to the household which pays for the expenses by using up savings or by borrowing from others. One of the reasons savings can increase financial satisfaction is because such savings can be reserved as the retirement funds which can free the respondents from worrying about their future retirement lives (Ali et al., 2015). Furthermore, savings can serve as personal reserve funds for use in times of emergency (Robb \& Woodyard, 2011). In view of this, the 
government can encourage people to spend wisely through moderate spending on necessary goods and less on luxury or designer goods. Furthermore, the government or policy makers can implement policies that encourage people to save more.

These empirical results also reveal a significant and positive relationship between income inequality and financial satisfaction (ologit coefficient $=0.06$, oprobit coefficient $=0.04$, p-value $=<0.01$ ) . This implies that Malaysians wish to have larger income differences as an incentive for individual effort. It is fair for people who work more and harder to expect to earn more as well. They would feel happy or more satisfied if the outcomes are perceived to be fair (Ordóñez, Conolly \& Coughlan, 2000). Instead of taxing the rich and subsidising the poor, the government should encourage employers to implement a reward system which gives incentives to those employees who put more effort into their work. This incentive reward system can increase productivity and work efficiency apart from the attainment of financial satisfaction.

Next, food security is also crucial in stimulating a higher financial satisfaction (ologit coefficient $=0.25$, oprobit coefficient $=0.14$, $\mathrm{p}$-value $=<0.05$ ) and being one of the basic human needs for survival. Hence, if there is enough money to purchase the basic needs, people tend to be happier with their financial situation compared to their counterparts who do not (Jaron \& Galal, 2009). As such, the government and the policy makers can consider to increase the subsidies or impose price controls on necessary goods such as rice, sugar, salt, flour and cooking oil. This will help ease some of the financial burdens for them to feel and be more financially satisfied.

On the demographic variables, it was found that only married people tend to have a higher financial satisfaction than those who were single (ologit coefficient $=0.33$, oprobit coefficient $=0.22$, p-value $=<0.05$ ) Bonke and Browning (2009) claimed that married individuals have higher incomes than single individuals. In Malaysia, most married couples work and generate double incomes for the household thus improving their financial situation and satisfaction. On the other hand, the single individuals have to be financially independent on a single income and because they tend to expect a higher income, they become less satisfied with their financial circumstances. Lastly, this analysis illustrates that working in the public sector, age and gender factors are not related to the probability of being financially satisfied. 
For a robustness check, financial satisfaction was re-scaled into binary responses and estimated Equation (1) with logit and probit modelling. The results obtained were consistent with the ordered logit and ordered probit modelling. Hence, as data sensitivity in this study is rather low, the results were quite consistent regardless of whichever model specifications were used.

The findings of this study illustrate a significant negative relationship between the individual perceptions on the Malaysian government's democratic act on "tax the rich, subsidise the poor" financial policy and financial satisfaction among Malaysians. This clearly indicates that Malaysians are not financially satisfied when the government taxes the higher income groups more and subsidises the lower income groups. This 'taxing the rich and subsidising the poor' policy may be seen as an unfair system where hard work is not given due recognition and appreciation (Gentry \& Hubbard, 2004). This can be further justified by the empirical evidence from this study on the independent variable-income inequality. Through this variable, this study reveals that Malaysians wished to have a larger income difference as an incentive for individual efforts to improve their financial situation and eventually, financial satisfaction. Besides, the study also demonstrates that income levels, financial situation, food security and marital status have positive impact on the financial satisfaction. Henceforth, the government and policy makers may look into these factors when making the policies which aim to boost financial satisfaction among its citizens. Also, the study demonstrates that working in the public sector or private sector, age and gender factors do not affect the financial satisfaction.

In a nutshell, the motive behind "tax the rich, subsidise the poor" policy by the Malaysian government to reduce income inequality between the different income groups, does not really make the people financially satisfied. In contrast, people wish to have this income inequality for their financial satisfaction as shown by the empirical findings in this study. Therefore, the study suggests that the government and policy makers may look further and deeper into the current progressive taxation practice in Malaysia, or look for other alternative taxation systems that can be seen as fairer and just to each income level to enhance financial satisfaction among its citizens. Rather than 'tax the rich and subsidise the poor', the government can urge companies to introduce remuneration systems that can 
motivate their workers to put in more efforts and be more efficient and productive at work. In short, a rewarding remuneration system will stimulate their financial satisfaction (Ali \& Akram, 2012).

Furthermore, based on the significant results on the income levels, financial situation, food security and marital status, it is recommended that the government may increase the minimum wages particularly, for the lowly-paid workers to support their expenditure budget for the basic necessary items and to make them financially satisfied. Moreover, an increment in the minimum wage can prompt them to save more for future consumptions (Dynan, Skinner \& Zeldes, 2004). Policy makers may also consider to launch various savings plans with appealing returns to encourage them to set aside more money for savings. In addition, the government can also provide citizens with vouchers to purchase their essential products. When these fundamental needs are fulfilled, the citizens will be satisfied and happy with their financial situation.

\section{Conclusion}

The paper concludes that the "tax the rich, subsidise the poor" policy does not create the financial satisfaction among Malaysians, but it may create unnecessary financial burden on the targeted group. Since it appears that the current practice of implementing a progressive tax system can ruin and lower financial satisfaction among Malaysians, it is suggested that future studies further investigate alternative taxation systems which can bring about fairness and financial satisfaction to Malaysians. Future studies should look into the moderators or any missing puzzles that can mitigate any financial dissatisfaction on 'taxing the rich, subsidising the poor'. Finally, future studies should also look for a reward or remuneration system which can motivate more productive and efficient individual efforts to improve the income levels, not only for the sake of an enhanced financial satisfaction but also, for higher productivity of the labour markets.

\section{References}

Alesina, A., Di Tella, R., \& MacCulloch, R. (2004). Inequality and happiness: Are Europeans and Americans different? Journal of Public Economics, 88(9-10), 2009-2042. 
Ali, A., \& Akram, M. N. (2012). Impact of financial rewards on employee's $\mathrm{s}$ motivation and satisfaction in pharmaceutical industry, Pakistan. Global Journal of Management and Business Research, 12(17).

Ali, A., Rahman, M. S. A., \& Bakar, A. (2015). Financial satisfaction and the influence of financial literacy in Malaysia. Social Indicators Research, 120(1), 137-156

Amarante, V. (2014). Revisiting inequality and growth: Evidence for developing countries. Growth and Change, 45(4), 571-589.

Ball, R., \& Chernova, K. (2008). Absolute income, relative income, and happiness. Social Indicators Research, 88(3), 497-529.

Bernstein, J. (2014, May). To lift the poor, you can't avoid taxing the rich. The New York Times. Retrieved from https://www.nytimes. com/2014/05/20/upshot/to-lift-the-poor-you-cant-avoidtaxing-the-rich.html

Białowolski, P. (2018). Hard times! How do households cope with financial difficulties? Evidence from the Swiss household panel. Social Indicators Research, 139(1), 147-161.

Blanchflower, D. G., \& Oswald, A. J. (2004). Well-being over time in Britain and the USA. Journal of Public Economics, 88, 1359-1386.

BNM. (2019). Budget 2020. Bank Negara Malaysia. Retrieved from https://www.bnm.gov.my/documents/budget/bs2020.pdf

Bonke, J., \& Browning, M. (2009). The distribution of financial wellbeing and income within the household. Review of Economics of the Household, 7(1), 31-42.

Briscoe, M. (1982). The sense of well-being in America. Recent patterns and trends. By A. Campbell (pp. 263; illustrated; £10.50.) McGraw-Hill: New York. 1981. Psychological Medicine, 12(2), 436-437.

Brown, S., \& Gray, D. (2016). Household finances and well-being in Australia: An empirical analysis of comparison effects. Journal of Economic Psychology, 53, 17-36.

Bruni, Luigino., \& Pier Luigi Porta (Eds.) (2007). Handbook on the economics of happiness. Cheltenham, UK: Edward Elgar.

Cheung, F., \& Lucas, R. E. (2016). Income inequality is associated with stronger social comparison effects: The effect of relative Income on life satisfaction. Journal of Personality and Social Psychology, 110, 332-341. doi.org/10.1037/pspp0000059

Cheung, F. (2018). Income redistribution predicts greater life satisfaction across individual, national, and cultural characteristics. Journal of Personality and Social Psychology, 115(5), 867-882. https://doi.org/10.1037/pspp0000164 
Cooper, D., McCausland, W. D., \& Theodossiou, I. (2013). Income inequality and wellbeing: The plight of the poor and the curse of permanent inequality. Journal of Economic Issues, 47(4), 939958.

Cutler, D. W. Gregg., \& M. P. Lawton (Eds.), Aging, money, and life satisfaction: Aspects of financial gerontology (pp. 69-99). New York: Springer.

Delhey, J., \& Dragolov, G. (2014). Why inequality makes Europeans less happy: The role of distrust, status anxiety, and perceived conflict. European sociological review, 30(2), 151-165. https://doi. org/10.1093/esr/jct033

DePianto, D. E. (2011). Financial satisfaction and perceived income through a demographic lens: Do different race/gender pairs reap different returns to income? Social Science Research, 40(3), 773-783.

Diener, E. (1984). Subjective well-being. Psychological Bulletin 95, pp. $542-575$.

Diener, E., \& Chan, M. Y. (2011). Happy people live longer: Subjective well-being contributes to health and longevity. Applied Psychology: Health and Well-Being, 3(1), 1-43.

Dynan, K. E., Skinner, J., \& Zeldes, S. P. (2004). Do the rich save more? Journal of political economy, 112(2), 397-444.

Ferrer-i-Carbonell, A., \& Gërxhani, K. (2011). Financial satisfaction and (in) formal sector in a transition country. Social Indicators Research, 102(2), 315-331.

Frank, R. (2013). Falling behind: How rising inequality harms the middle class (Vol. 4). Berkeley and Los Angeles, California: Univ of California Press.

Frijters, P. (2000). Do individuals try to maximize general satisfaction? Journal of Economic Psychology, 21(3), 281-304.

Gentry, W. M., \& Hubbard, R. G. (2004). The effects of progressive income taxation on job turnover. Journal of Public Economics, 88(11), 2301-2322.

Greenley, J. R., Greenberg, J. S., \& Brown, R. (1997). Measuring quality of life: A new and practical survey instrument. Social Work, 42, 244-254

Griffith, T. D. (2003). Progressive taxation and happiness. BCL Rev., $45,1363$.

Hagerty, M. R. (2000). Social comparisons of income in one's community: Evidence from national surveys of income and happiness. Journal of Personality and social Psychology, 78(4), 764. 
Hakim, R. A. (2000). Income inequality in Malaysia: A decomposition analysis by income sources. International Journal of Management Studies, Analysis, 7(1\&2), 45-60.

Hamid, H. A. (2020). Benarkah Jurang miskin, kaya Malaysia makin lebar? Khazanah Research Institute Views. Retrieved from http://www.krinstitute.org//assets/contentMS/img/template/ editor/20200125

Hansen, T., Slagsvold, B., \& Moum, T. (2008). Financial satisfaction in old age: A Satisfaction paradox or a result of accumulated wealth? Social Indicators Research, 89, 323 347. https://doi. org/10.1007/s11205-007-9234-z

Hastings, O. P. (2019). Who feels it? Income inequality, relative deprivation, and financial satisfaction in US states, 1973-2012. Research in Social Stratification and Mobility, 60, 1-15.

Heckman, J. J., \& Hotz, V. J. (1986). An investigation of the labour market earnings of Panamanian males: Evaluating the sources of inequality. Journal of Human Resources, 21, 507-542.

Helliwell, J. F., Layard, R., \& Sachs, J. (2012). World happiness report. Retrieved from https://open.library.ubc.ca/cIRcle/collections/ facultyresearchandpublications/52383/items/1.0053622

Hicks, S., Tinkler, L., \& Allin, P. (2013). Measuring subjective wellbeing and its potential role in policy: Perspectives from the UK office for national statistics. Social Indicators Research, 114(1), 7386.

Hira, T. K., \& Mugenda, O. M. (1998). Predictors of financial satisfaction: Differences between retirees and non-retirees. Journal of Financial Counselling and Planning, 9(2), 75.

Hsieh, C. (2004). Income and financial satisfaction among older adults in the United States. Social Indicators Research. 66, 249-266.

Hsieh, C.-M. (2003). Income, age and financial satisfaction. The International Journal of Aging and Human Development, 56(2), 89112.

Huston, S. J. (2010). Measuring financial literacy. Journal of Consumer Affairs, 44(2), 296-316.

Inglehart, R., C. Haerpfer, A. Moreno, C. Welzel, K., Kizilova, J. DiezMedrano, M. Lagos, P. Norris, E. Ponarin., \& B. Puranen et al. (Eds.). (2014). World values survey: Round six - country-pooled datafile version. Madrid: JD Systems Institute.

Jaron, D., \& Galal, O. (2009). Food security and population health and well-being. Asia Pacific Journal of Clinical Nutrition, 18(4), 684. 
Joo, S. (2008). Personal financial wellness. In: Xiao J.J. (Eds.), Handbook of consumer finance research. Springer. New York, NY. https:// doi.org/10.1007/978-0-387-75734-6_2.

Joo, S. H. (1998). Personal financial wellness and worker job productivity (Unpublished doctoral dissertation) Virginia Polytechnic Institute and State University, Blacksburg.

Joo, S. H., \& Grable, J. E. (2004). An exploratory framework of the determinants of financial satisfaction. Journal of family and economic Issues, 25(1), 25-50.

Khalid, K. A. (2012). Malaysia household wealth distribution: Current evidence and future prospects. International Journal of Management Studies, 19(1), 73-86.

Khazanah Research Institute. (2018). The state of households 2018: Different realities. Retrieved from http://www.krinstitute. org/assets/contentMS/img/template/editor/FullReport_KRI_ SOH_2018.pdf

KPMG (2020). Individual income tax rates table. KPMG open data. Retrieved from https:/home.kpmg/xx/en/home/services/tax/ tax-tools-and-resources/tax-rates-online/individual-incometax-rates-table.html

Larson, R. (1978). Thirty years of research on the subjective well-being of older Americans. Journal of Gerontology, 33, 109-125.

Lu, J. (January, 2019). Tax the ultrarich to solve poverty? Easier said than done. NPR. Retrieved from https://www.npr.org/sections/ goatsandsoda/2019/01/25/688345610/tax-the-ultra-rich-tosolve-poverty-easier-said-than-done

Luechinger, S., Meier, S., \& Stutzer, A. (2010). Why does unemployment hurt the employed? Evidence from the life satisfaction gap between the public and the private sector. Journal of Human Resources, 45(4), 998-1045.

Luttmer, E. F. (2005). Neighbours as negatives: Relative earnings and well-being. The Quarterly Journal of Economics, 120(3), 963-1002.

Mafini, C., \& Dlodlo, N. (2014). The relationship between extrinsic motivation, job satisfaction and life satisfaction amongst employees in a public organisation. SA Journal of Industrial Psychology, 40(1), 01-12.

McGee, R. W., Benk, S., \& Yüzbaşı, B. (2019). Should governments tax the rich and subsidize the poor? A comparative study of Muslim and Christian respondents. Religions, 10(2), 72.

McGee, R. W., \& Yoon, Y. (2018). Should governments tax the rich and subsidize the poor? An empirical study of South Korean opinion. Journal of Accounting, Ethics and Public Policy, 19(1). 
McGee, R. W., Yoon, Y., \& Liu, Z. (2019). Should governments tax the rich and subsidize the poor? An empirical study of German opinion. Journal of Accounting, Ethics and Public Policy, 20(2), 201223

Migheli, M. (2019). Religious polarization, religious conflicts and individual financial satisfaction: Evidence from India. Review of Development Economics, 23(2), 803-829.

Morgan, J. N. (1992). Health, work, economic status, and happiness. Aging, money, and life satisfaction: Aspects of financial gerontology, 101-133.

Ng, W., \& Diener, E. (2014). What matters to the rich and the poor? Subjective well-being, financial satisfaction, and postmaterialist needs across the world. Journal of Personality and Social Psychology, 107(2), 326.

Ng, W., Russell Kua, W. S., \& Kang, S. H. (2019). The relative importance of personality, financial satisfaction, and autonomy for different subjective well-being facets. The Journal of Psychology, 153(7), 680700 .

Ngamaba, K. H., Armitage, C., Panagioti, M., \& Hodkinson, A. (2020). How closely related are financial satisfaction and subjective wellbeing? Systematic review and meta-analysis. Journal of Behavioral and Experimental Economics, 85, 101522.

Oishi, S., Schimmack, U., \& Diener, E. (2012). Progressive taxation and the subjective well-being of nations. Psychological Science, 23(1), 86-92. https://doi.org/10.1177/0956797611420882

Ordóñez, L. D., Connolly, T., \& Coughlan, R. (2000). Multiple reference points in satisfaction and fairness assessment. Journal of Behavioural Decision Making, 13(3), 329.

Oxfam. (2019). Public goods or private health. Oxfam briefing paper. Retrieved from https:/oxfamilibrary.openrepository.com/ bitstream/handle/10546/620599/bp-public-good-or-privatewealth-210119-summ-en.pdf?utm_source=indepth

Pisani, M. J., \& Pagán, J. A. (2003). Sectoral queuing in a transitional economy: The case of Nicaragua in the 1990s. Labour, 17, 571-597.

Plagnol, A. C. (2011). Financial satisfaction over the life course: The influence of assets and liabilities. Journal of Economic Psychology, 32(1), 45-64.

Pradhan, M., \& Van Soest, A. (1995). Formal and informal sector employment in urban areas of Bolivia. Labour Economics, 2(3), 275-297.

Ravallion, M., \& Lokshin, M. (2000). Who wants to redistribute? The tunnel effect in 1990s Russia. Journal of Public Economics, 76(1), 87-104. 
Richard A. E. (1974). Does economic growth improve the human lot? Some empirical evidence. Nations and Households in Economic Growth, Academic Press, 89-125. doi.org/10.1016/B978-0-12205050-3.50008-7.

Robb, C. A., \& Woodyard, A. (2011). Financial knowledge and best practice behaviour. Journal of Financial Counselling and Planning, 22(1), 60-70.

Roth, B., Hahn, E., \& Spinath, F. M. (2017). Income inequality, life satisfaction, and economic worries. Social Psychological and Personality Science, 8(2), 133-141. https://doi. org/10.1177/1948550616664955

Safari, M. A. M., Masseran, N., \& Ibrahim, K. (2018). A robust semiparametric approach for measuring income inequality in Malaysia. Physica A: Statistical Mechanics and Its Applications, 512, $1-13$.

Sahi, S. K. (2013). Demographic and socio-economic determinants of financial satisfaction. International Journal of Social Economics, 40(2), 127-150.

Saravanamuttu, J., \& Mohamad, M. (2020). The monetisation of consent and its limits: Explaining political dominance and decline in Malaysia. Journal of Contemporary Asia, 50(1), 56-73.

Senik, C. (2005). Income distribution and well-being: What can we learn from subjective data? Journal of Economic Surveys, 19(1), 43-63.

Stack, S., \& Eshleman, J. R. (1998). Marital status and happiness: A 17-nation study. Journal of Marriage and the Family, 60(2), 527-536.

Ta, Y., Zhu, Y., \& Fu, H. (2020). Trends in access to health services, financial protection and satisfaction between 2010 and 2016: Has China achieved the goals of its health system reform? Social Science \& Medicine, 245, 112715.

Thomas, J.J. (1990). Synthesis of comments and discussion: Methodology and theory (of the informal sector). Turnham, 1990, 88-92.

Vera-Toscano, E., Ateca-Amestoy, V., \& Serrano-Del-Rosal, R. (2006). Building financial satisfaction. Social Indicators Research, 77(2), 211-243.

World Bank, T. (2018). World Bank open data. World Bank Website. Retrieved https://www.worldbank.org/

World Values Survey Association. (2009). World values survey 19812008 official aggregate v. 20090901. Madrid: ASEP/JDS.

Yan, B., \& Wen, B. (2020). Income inequality, corruption and subjective well-being. Applied Economics, 52(12), 1311-1326. doi: 10.1080/00036846.2019.1661953

Zimmerman, S. L. (1995). Understanding family policy: Theories and applications (2nd ed.). Thousand Oaks, CA: Sage. 